\title{
SUB-CHRONIC COMBINED TOXIC EFFECT OF ETHEPHON AND GIBBERELLIC ACID ON MICE BRAIN MITOCHONDRIAL ADENOSINE TRI-PHOSPHATASES AND BOTH BRAIN AND WHOLE BLOOD ACETYLCHOLINEESTERASE El-Okazy, A. M. \\ Regional Center for Food \& Feed - Agricultural Research Center - Alexandria, Egypt.
}

\section{ABSTRACT}

The objective of the present study was to assess the sub-chronic effect of combination between ethephon and gibberellic acid on brain mitochondrial adenosine tri-phosphatas, brain and whole blood acetyl cholinesterase. Male ICR (CD-1) mouse was used as an experimental model. The experiment duration was 23 weeks through which animals received diets containing ethephon in a series of concentrations of 0 , 25,50 and 75 milligram per kilogram diet respectively with and without $50 \mathrm{mg}$ of gibberellic acid. A significant variation was recorded between the effect of ethephon and that of ethephon - gibberellic acid combination on the activity of total mitochondrial ATPase in mice brain $(P \leq 0.05)$. Gibberellic acid antagonized the inhibition occurred by ethephon in case of the two smaller dietary concentrations 25 and $50 \mathrm{mg} / \mathrm{kg}$ diet. Ethephon induced a highly significant ( $p \leq 0.01)$ concentrationdependent activation in $\mathrm{Mg}^{+2}$ ATPase in animals exposed to the two lower dietary concentrations 25 and $50 \mathrm{mg} / \mathrm{kg}$ with and without gibberellic acid. Ethephon induced a highly significant $(\mathrm{p} \leq 0.01)$ dietary concentration-dependent inhibition in brain $\mathrm{Na}^{+} /$ $\mathrm{K}^{+}$ATPase. Gibberellic acid obviously reduced inhibition in animals received the two smaller concentrations (25 and $50 \mathrm{mg} / \mathrm{kg}$ diet). No significant variation was found in brain acetyl cholinesterase neither among treated groups nor between these groups and the control $(p \geq 0.05)$. Gibberellic acid induced a highly significant recovery in the inhibited whole blood AChE in groups fed the low concentrations of 25 and $50 \mathrm{mg} / \mathrm{kg}$ diet $(p \leq 0.01)$. While at higher concentration $(75 \mathrm{mg} / \mathrm{kg}$ diet) gibberellic acid showed an additive inhibitory effect on whole blood AChE.

Keywords: Plant Growth Regulators, Ethephon, Gibberellic acid, Diet, Adenosine triphosphatase, Acetyl cholinesterase, Mice,

\section{INTRODUCTION}

Many types of chemicals have been extensively used in agriculture, and plant growth regulators are among those widely employed (Mickel 1978). Ethephon is an organophosphorus plant growth regulator that, upon absorption into plants, forms ethylene gas which is an important component of the plant hormone complex. Ethephon is currently registered for use on many vegetables fruits and grain crops (Kidd and James, 1991). Gibberellic acid-3 (GA-3) is a naturally occurring plant growth regulator which may cause stimulation of seed germination and cell elongation. Gibberellic acid-3 is heatresistant, not losing its activity after 4 hours at $100^{\circ} \mathrm{C}$ (Deno 1993). Many different gibberellins are present in common plants like rice, corn, wheat and barley (Tamura 1990).

The toxic effects of organophosphorus compounds are primarily based on inhibition of acetylcholinesterase (AChE) enzyme which participates in the transfer of impulse in central synapses of the cholinergic nervous 
system through a chemical mediator, acetylcholine. At the same time, organophosphates and their metabolites have been reported to inhibit adenosine tri-phosphatase in animal tissues (Krstic et al., 2007). Chronic dietary toxicity studies on mice and rats proved that ethephon induced a significant dose-related inhibition of plasma and RBC cholinesterase activity in males and females (United States Environmental Protection Agency, 1988 and 2006).

Tuluce and Celike, (2006) reported that GA3 induced sub acute and sub chronic adverse effects on serum marker enzymes and erythrocytes in rats when exposed to $75 \mathrm{ppm}$ of GA3 in drinking water for 50 days. El-Okazy (2008) proved that gibberellic acid slightly reduced the inhibitory effect of acute oral doses of ethephon on mice brain acetylcholinesterase.

The aim of the present study is to investigate the effect of sub chronic dietary exposure to combination between ethephon and gibberellic acid on some enzyme activities in mice brain and blood.

\section{MATERIALS AND METHODS}

1-Tested materials:

a- Ethephon (2-chloroethylphosphonic acid), Hockley-phone 48, 480 gram per liter, supplied by Hockley International LTD, UK.

b- Gibberellic acid (PROGIB 40\%) supplied by Valent BioSciences corporation, U.S.A.

\section{2- Experimental animals:}

Seventy male ICR (CD-1) mice, two months-old of a mean body weight of $21.35 \pm 2.91 \mathrm{~g}$ were supplied from the Animal House of the Reproductive Toxicology Lab. Faculty of Agriculture, Alexandria University two weeks before treatments and adapted to the condition of the Animal House at the Regional Center for Food and Feed, Agricultural Research Center, Dekheila, Alexandria. Mice were housed in stainless steel cages and divided into seven groups of ten mice each. The experiment duration was 23 weeks during which animals were fed a regular rabbits diet (contains $18 \%$ crude protein, $2.8 \%$ crude fat, $12 \%$ crude fibers and $1 \%$ vitamins and minerals premix). Treatments were added to the diet by dilution with water and spraying on the prepared diet and then air dried in cool and dark place every week. Group I received a regular diet and was referred to as control group. Groups II, III and IV received diets containing ethephon in a series of concentrations of 25, 50 and 75 milligram per kilogram of feed respectively. Groups V, VI and VII received diets containing ethephon in a series of concentrations of 25,50 and 75 milligram per kilogram of feed respectively in addition to gibberellic acid in a concentration of 50 milligram per kilogram of the diet for each concentration of ethephon. At the end of the experiment, animals were anesthetized and autopsied. Brains were removed, weighed and divided into two halves. The first half was homogenized in 10 volumes $(\mathrm{w} / \mathrm{v})$ of $0.1 \mathrm{M}$ phosphate buffer of $\mathrm{pH} 7.4$ using polytron homogenizer for thirty seconds. The homogenates were then centrifuged at $6000 \times \mathrm{G}$ for 20 minute at $4^{\circ} \mathrm{C}$ using a Sorvall RC 50 Plus High Speed Centrifuge. The supernatants were stored at $-20^{\circ} \mathrm{C}$ until protein determination and enzyme assays. The second half was prepared for mitochondria separation. 


\section{Preparation of brain mitochondrial ATPase:}

Mitochondria were prepared according to Koch (1969). Brains were dissected and placed in ice-cold medium containing $0.25 \mathrm{M}$ sucrose, $1 \mathrm{mM}$ ethylene diamine tetra acetic acid (EDTA), and $20 \mathrm{mM}$ tris- $\mathrm{HCl}, \mathrm{pH} 7.4$ they were homogenized using polytron homogenizer for 30 seconds and filtered through a double layers of cheese cloth. The filtrates were centrifuged at $3000 \mathrm{rpm}$ for 10 minutes at $4^{\circ} \mathrm{C}$ using a Sorvall RC 50 plus High Speed Centrifuge. The supernatants were further centrifuged at $11,000 \mathrm{rpm}$ for 20 minutes at $4^{\circ} \mathrm{C}$. The pellets containing mitochondria were washed twice with $0.25 \mathrm{M}$ sucrose, $1 \mathrm{mM}$ ethylene diamine tetra acetic acid (EDTA) $\mathrm{pH} 7.4$ and centrifuged as before. The pellets were re-suspended in the same buffer using a glass homogenizer, and stored at $-20^{\circ} \mathrm{C}$.

Determination of protein in tissue and mitochondrial homogenates:

Protein of brain homogenates and mitochondria was determined using the method of Bradford (1976). $50 \mu \mathrm{l}$ of $1 \%$ solution of Triton X 114 was added to $20 \mu \mathrm{l}$ protein aliquot (to increase protein solubility), the volume was made up to $100 \mu \mathrm{l}$ with the homogenizing buffer and shaken well .The mixture was left for five minutes at room temperature, then $4.9 \mathrm{ml}$ of Coomassie blue $\mathrm{G} 250$ reagent ( $0.1 \mathrm{~g}$ coomassie brilliant blue $\mathrm{G} 250$ in 50 $\mathrm{ml}$ ethanol $95 \%, 100 \mathrm{ml}$ phosphoric acid $85 \%$ and the solution was completed to a final volume of $1000 \mathrm{ml}$ with distilled water and filtered ) was added and mixed well then incubated at room temperature for 2 minutes. The developed color was measured at $595 \mathrm{~nm}$ against reagent blank using a Turner U 500 UV / Vis. Spectrophotometer at the Regional Center for Food and Feed, Agricultural Research Center, Alexandria.

\section{Acetyl Cholinesterase assays:}

Cholinesterase activity was assayed according to the method of Ellman et al. (1961) which depends on measuring the increase of yellow color produced from thiocholine when it reacts with dithiobis - 2 nitrobenzoate ion. The reaction mixture contained $2.9 \mathrm{ml}$ of $0.1 \mathrm{M}$ phosphate buffer $\mathrm{pH} 7.4$ and $20 \mu \mathrm{l}$ of the enzyme preparation, the mixture was shaken and then $50 \mu \mathrm{l}$ of the substrate of $0.075 \mathrm{M}$ acetylthiocholine iodide was added. The absorbance of the developed yellow color was recorded at $412 \mathrm{~nm}$. AChE activity is expressed as optical density / g protein / minute.

\section{Adenosin triphosphatase (ATPase) assay:}

Brain mitochondrial adenosine triphosphatase (ATPase) activity was assayed according to the method of Cutkomp et al. (1971) by measuring the concentration of inorganic phosphate liberated by the hydrolysis of adenosin triphosphate (ATP). 20 - $40 \mu \mathrm{l}$ aliquots (containing 20-40 $\mu \mathrm{g}$ protein) from the mitochondrial preparation of brain tissues were mixed with ATPase reaction mixture to a final volume of $850 \mu \mathrm{l}$. The reaction mixture is composed of: 50 $\mathrm{mM}$ tris $\mathrm{HCl} \mathrm{pH} 8 ; 5 \mathrm{mM} \mathrm{MgCl} ; 50 \mathrm{mM} \mathrm{KCl}$ (all were analytical grade reagent). The total volume was completed to $0.9 \mathrm{ml}$ by adding $50 \mu \mathrm{l}$ of $5 \mathrm{mM}$ ATP. The mixture was incubated for 30 minutes at $37^{\circ} \mathrm{C}$ in a shaking water bath. The reaction was terminated by adding $0.1 \mathrm{ml}$ of $50 \%$ ice-cold solution of trichloroacetic acid to a final volume of $1 \mathrm{ml}$. In order to measure the amount of inorganic phosphate released $4 \mathrm{ml}$ of freshly prepared ferrous sulfate $\mathrm{FeSO}_{4} .7 \mathrm{H}_{2} \mathrm{O}$ solution in ammonium molybdate (Taussky and Shurr 
1953). The absorbance of the blue color was red at $740 \mathrm{~nm}$ against sample blank in which the TCA was added before the enzyme to prevent its function .The absorbance obtained was compared to a standard curve of known phosphate concentrations between 0.1-1.0 $\mu$ moles of $\mathrm{NaH}_{2} \mathrm{PO}_{4}$.

The activity of adenosine triphosphatase was expressed as $\mu$ mole of inorganic phosphate per $\mathrm{mg}$ protein per minute. $\mathrm{Mg}^{2+}$ ATPase activity was measured when $0.85 \mathrm{~m} \mathrm{M}$ ouabain (the specific inhibitor of $\mathrm{Na}^{+} / \mathrm{K}^{+}$ATPase) was added to the reaction mixture. $\mathrm{Na}^{+} / \mathrm{K}^{+}$ATPase activity is the total ATPase activity minus the $\mathrm{Mg}^{+2}$ ATPase activity.

Statistical analysis:

Presentation of data and statistical analysis of the results were carried out using the analysis of variance (ANOVA) and Fisher's least difference (LSD) according to Steel and Torrie (1981).

\section{RESULTS AND DISCUSSION}

1- The effects of combination between ethephon and gibberellic acid in diet on mice brain mitochondrial adenosine tri-phosphatase (ATPase) activity:

The activity of adenosine tri-phosphatase is considered a good index of cellular activity and useful toxicological indicator (Reedy et al. (1992). Table 1 represents the effects of sub-chronic dietary exposure of the tested materials on the activity of mice brain mitochondrial ATPase activity. It was found that there is a statistically significant difference between the effect of ethephon and that of ethephon - gibberellic acid combination on the activity of total mitochondrial ATPase in mice brain under the present study condition $(P \leq$ 0.05). The inhibitory effect of organophosphates on adenosinetriphosphatase was established in both mammals and non mammals (Ibrahim 1991, Reedy et al., 1992 and Habiba and Ismail 1992).

Table 1: The effect of sub-chronic dietary exposure to tested materials on mice brain mitochondrial ATPase activity:

\begin{tabular}{|c|c|c|c|c|}
\hline \multirow{2}{*}{\multicolumn{2}{|c|}{ Group treatments ( $\mathrm{mg} /$ kg diet ) }} & $\begin{array}{c}\text { Total } \\
\text { ATPase }\end{array}$ & $\begin{array}{c}\mathrm{Mg}^{++} \\
\text {ATPase }\end{array}$ & $\begin{array}{c}\mathrm{Na}^{+} \mathrm{K}^{+} \\
\text {ATPase }\end{array}$ \\
\hline & & \multicolumn{3}{|c|}{ ( $\mu$ mole $\mathrm{Pi} / \mathrm{mg}$ protein / minute) } \\
\hline \multicolumn{2}{|l|}{ (0) Control } & $1.21 \pm 0.48$ & $0.28 \pm 0.13$ & $0.88 \pm 0.15$ \\
\hline \multicolumn{2}{|l|}{ II (25 mg ethephon / kg) } & $1.02 \pm 0.47$ & $0.32 \pm 0.09$ & $0.90 \pm 0.16$ \\
\hline \multicolumn{2}{|l|}{ III (50 mg ethephon / kg ) } & $0.86 \pm 0.26$ & $0.43 \pm 0.08$ & $0.46 \pm 0.09$ \\
\hline \multicolumn{2}{|l|}{ IV (75 mg ethephon /kg ) } & $0.74 \pm 0.27$ & $0.27 \pm 0.13$ & $0.47 \pm 0.11$ \\
\hline \multicolumn{2}{|c|}{ V (25 mg ethephon + 50 mg gibberillic acid / kg) } & $1.24 \pm 0.36$ & $0.32 \pm 0.09$ & $0.87 \pm 0.12$ \\
\hline \multicolumn{2}{|c|}{ VI ( $50 \mathrm{mg}$ ethephon $+50 \mathrm{mg}$ gibberillic acid $/ \mathrm{kg}$ ) } & $1.23 \pm 0.64$ & $0.37 \pm 0.19$ & $0.82 \pm 0.15$ \\
\hline \multicolumn{2}{|c|}{ VII (75 mg ethephon $+50 \mathrm{mg}$ gibberillic acid $/ \mathrm{kg}$ ) } & $0.83 \pm 0.37$ & $0.31 \pm 0.16$ & $0.54 \pm 0.14$ \\
\hline \multicolumn{5}{|c|}{ Values of estimated $F$ : } \\
\hline Source of variance & Total ATPase & Mg $^{++}$ATPase & \multicolumn{2}{|c|}{$\mathrm{Na}^{+} \mathrm{K}^{+}$ATPase } \\
\hline \multirow{4}{*}{$\begin{array}{l}\text { Treatments } \\
\text { LSD (treatments) } \\
\text { Dose } \\
\text { LSD (Doses) }\end{array}$} & $4.55^{*}$ & \multirow{4}{*}{$\begin{array}{c}0.018 \\
0.04579137362 \\
5.44^{\star *} \\
0.06835393396\end{array}$} & \multirow{4}{*}{\multicolumn{2}{|c|}{$\begin{array}{c}69.57^{\star \star} \\
0.02447204858 \\
117.7^{\star \star} \\
0.068702073\end{array}$}} \\
\hline & 0.161945039 & & & \\
\hline & 1.72 & & & \\
\hline & 0.4124790953 & & & \\
\hline
\end{tabular}

$\mathbf{N}=\mathbf{5}$

*: Significant variation at 0.05 level of significance

$\star \star$ : Highly Significant variation at 0.01 level of significance. 
Addition of gibberellic acid to the diet remarkably changed the figure in case of the two smaller dietary concentrations 25 and $50 \mathrm{mg} / \mathrm{kg}$ diet. Gibbereillic acid recovered the inhibition occurred by ethephon to values similar to those of the control group. It was also noted that there was no significant difference between the effect of ethephon and combination with gibberellic acid on the activity of $\mathrm{Mg}^{+2}$ ATPase in mice brain $(P \geq 0.05)$. Ethephon induced a highly significant $(\mathrm{p} \leq 0.01)$ activation of $\mathrm{Mg}^{+2}$ ATPase in animals exposed to the two lower dietary doses 25 and $50 \mathrm{mg} / \mathrm{kg}$ with and without gibberellic acid. The activation is recovered to the control level at the $75 \mathrm{mg} / \mathrm{kg}$ dietary concentration.

$\mathrm{Na}^{+} / \mathrm{K}^{+}$ATPase enzyme is associated with lipoproteins on membrane structure (Nakao et al., 1974). Kinter et al. (1972) speculated that lipophilic compounds exert biological effect on ATPase system which would induce partitioning in the enzyme complex. Table 1 showed that there was a highly significant $(p \leq 0.01)$ difference between the effect of ethephon alone and ethephon with gibberellic acid on the activity of brain $\mathrm{Na}^{+} / \mathrm{K}^{+}$ATPase. Although ethephon induced a highly meaningful dose dependent inhibition in the enzyme activity, Gibberellic acid obviously reduced such inhibition in animals fed on the two smaller concentrations $(25$ and $50 \mathrm{mg} / \mathrm{kg}$ ).

2-The effects of combination between ethephon and Gibberellic acid in diet on mice brain and whole blood AChE activity:

Many organophosphates are undergoing increasing restriction (United States Environmental Protection Agency EPA 2000 and 2002) because of their neurotoxic effect (Barone et al., 2000, Rice and Barone, 2000, Landrigan, 2001 and Casida and Quistad, 2004).

Table 2 exhibits the effect of sub-chronic dietary exposure to ethephon and ethephon gibberellic acid combination on the activity of brain and whole blood acetyl cholinesterase. It was found that there is no significant difference between the effect of ethephon alone and ethephon in combination with gibberellic acid on the enzyme activity $(p \geq 0.05)$. It was also found that there is no significant variation in brain acetyl cholinesterase neither among groups fed on various dietary concentrations nor between these groups and the control $(p \geq 0.05)$.

Table 2 also showed that there is no significant difference between the effect of ethephon alone or ethephon in combination with gibberellic acid on the activity of whole blood acetyl cholinesterase $(p \geq 0.05)$. Both treatments induced inhibition in whole blood AChE than the control group. The United States Environmental Protection Agency (EPA) (2006) reported that the most sensitive indicator of exposure to ethephon is the inhibition of red blood cell and plasma cholinesterase which occurs at low levels of exposure and may not be accompanied by clinical signs of toxicity until a threshold level of exposure is reached. Organophosphorus compounds have been classified as phosphorylating agents that inhibit Acetylcholinesterase. The toxic effects of ethephon on esterases are mediated through other reactive moiety (Casida and Toia, 1992). 
El-Okazy, A. M.

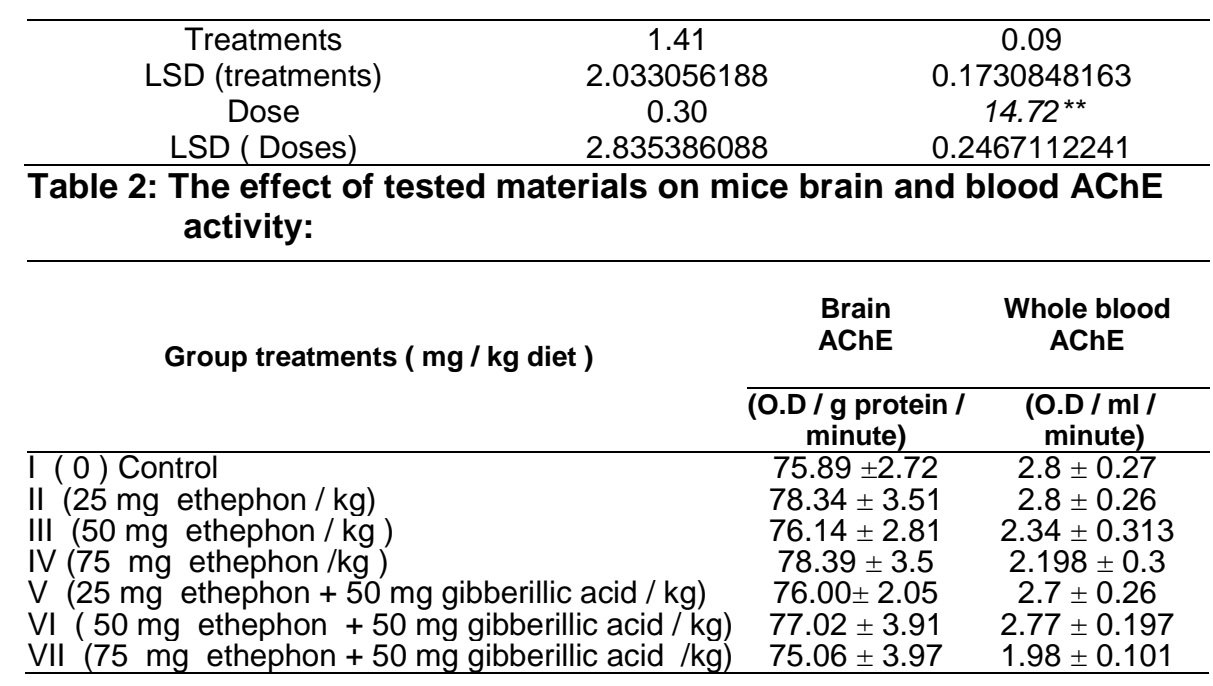

\section{Values of estimated $F$ :}

$\mathrm{N}=5$

**: Highly Significant variation at 0.01 level of significance.

On the hand it was noted that gibberellic acid induced a highly significant recovery of the inhibited whole blood AChE in groups fed the low concentrations $(p \leq 0.01)$. Then at higher concentration $75 \mathrm{mg} / \mathrm{kg}$ gibberellic acid showed an additive inhibitory effect on whole blood AChE. These findings agree with those of El-Okazy (2008).

United States Environmental Protection Agency EPA (1988) reported that no clinical signs of toxicity were encountered in rats received dietary concentrations of gibberellic acid up to $1000 \mathrm{ppm}$. Combination between ethephon and gibberellic acid in a sub-acute toxicity study of El-Okazy (2008) proved an additive dose dependent effect on many physiological paramrters in mice.

From the obtained results it could be generally concluded that the toxic effect of small dietary concentrations of ethephon ( up to $50 \mathrm{mg} / \mathrm{kg}$ ) on the studied parameters were buffered in presence of a small concentration of gibberellic acid. On the other hand small concentration of gibberellic acid may show an additive effect of high ethephon dietary concentration $(75 \mathrm{mg} / \mathrm{kg})$.

\section{REFERENCES}


Barone S, Das KP, Lassiter TL, White LD. 2000. Vulnerable processes of nervous system development: a review of markers and methods. Neurotoxicology 21:15-36.

Bradford M.M. (1976). A rapid and sensitive method for the quantitative microgram quantities of protein utilizing the principle of protein - dye binding. Anal Biochem . $72: 248-54$.

Casida JE, Quistad GB. 2004. Organophosphate toxicology: safety aspects of nonacetylcholinesterase secondary targets. Chem. Res. Toxicol. 17:983-998.

Casida JE, Toia RF Organophosphorus Pesticides: 33-70. Cited [1992/01/01]. Available from : http://toxnet.nlm.nih.gov/cgi in/sis/search/f?./temp/ AAAS_aiwC: 7ETHEPHON CASRN: 16672-870. 1992.

Cutkomp L. K., Yap H. H., Cheng E. Y. and Koch R. B. (1971). ATPase activity in fish tissue homogenates and inhibitory effects of DDT and related compounds. Chem.Biol. Interact. 3:439-47.

Deno NC. Seed germination, theory and practice. 2nd ed. Norman C. Deno, Pennsylvania State University, State College 1993; PA: 242.

Ellman G, L Jr Andress V, Featherstone RM. (1961). A new and rapid colorimetric determination of acetylcholinesterase activity. Biochem Pharmacol 7: 88-95.

El-Okazy A. M. (2008). The effects of Combination of Gibberellic acid -3 (GA3) and Ethephon (2- Chloroethyl Phosphonic Acid) (Plant Growth Regulators) on Some Physiological Parameters in mice. J. Egypt Public Health Assoc; 83(1-2):67-86.

Habiba R. A. and Ismail S. M. (1992). Biochemical effects of profenofos in the NewZealand White Rabbits. J. Pest Control \& Environ. Sci. 4(10):1529.

Ibrahim H. Z. (1991). Effect of endosulfan, triphenyltin acetate, thiodicarb and lambda-cyhalothrin on the activity of some enzymes in cat fish (Ictalurus punctaatus) tissues. J. Pest Control \& Environ. Sci., 3(10):114-26.

Kidd, H. and James, D. R., Eds. (1991) The Agrochemicals Handbook, Third Edition. Royal Society of Chemistry Information Services, Cambridge, UK, 10-2

Kinter W. B., Mekens L. S., Janiki R. H. and Guarino A. M. (1972). Studies on the mechanism of DDT and PCBs: Disruption of osmoregulation in marin fish. Environ. Health Press. 8:169-173.

Koch R. B. (1969). Chlorinated hydrocarbon insecticides: Inhibitionof rabbit brain ATPase activities. J. Neurochem.16: 269-71.

Krstic D., Colovic M., Vujacic A., Djuric D., Vasic V.(2007) The Influence of Chloropyriphos on NA+,K+-ATPASE Activity. Acta Physiologica 2007; Volume 191, Supplement 658. Joint Meeting of The Slovak Physiological Society, The Physiological Society and The Federation of European Physiological Societies 11-14/09/2007 Bratislava, Slovakia 


\section{El-Okazy, A. M.}

Landrigan PJ. 2001. Pesticides and polychlorinated biphenyls (PCBs): an analysis of the evidence that they impair children's neurobehavioral development. Mol. Genet. Metab. 73:11-17.

Mickel L. G.(1978) Plant growth regulators controlling biological behavior with chemicals, Chem. Eng. News 56. P. 18.

Nakao M., Nakao T. Hara Y., Nagi F., Ygassaki S., Koi M., Nakagawa A., Kawai K. (1974). Purification and properties of $\mathrm{Na}+\mathrm{K}+$ ATPase from guinea pig brain. Ann N. Acad. Sci. 242:24-33.

Reedy A. N., Venugapal N. B., Reddy S. L. (1992). Effect of indusulfan 35 EC on ATPase in the tissue of freshwater field carb Barytelphusa guerini. Bull. Environ. Contamin. Toxicol.,48:216-22.

Rice D, Barone S. 2000. Critical periods of vulnerability for the developing nervous system: evidence from humans and animal models. Environ. Health Perspect. 108 (suppl. 3):511-533.

Steel RG, Torrie JH. (1981). Principles and Procedures of Statistics. 2nd ed USA: Me Graw- Hill, Inc., 1981.

Tamura S. Historical aspects of gibberellins. In: Takahashi N, Phinney BO, Macmillan, (editors) Gibberellins: New York. Springer-Verlag 1990 ;p 18.

Taussky H. H. and Shurr E. (1953). A micro colorimetric method for the determination of inorganic phosphorous. J. Biol. Chem. 202:675-85

Tuluce Y, Celik I. (2006). Influence of subacute and subchronic treatment of abcisic acid and gibberellic acid on serum marker enzymes and erythrocyte and tissue antioxidant defense systems and lipid peroxidation in rats. Pesticide Biochemistry and Physiology.; 8(6):8592.

United State Environmental Protection Agency (1988). Guidance for the Reregistration of Pesticide Products Containing Ethephon as the Active Ingredient. US EPA, Office of Pesticide Programs, Registration Div., Washington, DC.

United State Environmental Protection Agency (2006). HUMAN STUDIES REVIEW BOARD (HSRB), APRIL 4-6, PUBLIC MEETING REPORT.

United States Environmental Protection Agency (1998). Gibberellic acid Tolerence Exemption 10 / 98, Federal Register: October 23,1998; 63:205.

United States Environmental Protection Agency (EPA) (2006). Report of the Food Quality Protection Act (FQPA) Tolerance Reassessment and Risk Management Decision (TRED) for Ethephon. EPA 738-R-05-005. June 15, 2006.

United States EPA (U.S. Environmental Protection Agency). (2000) Administrator's Announcement. Available: http://www.epa. gov/pesticides/announcement6800.htm

United States EPA (U.S. Environmental Protection Agency). (2002) Chlorpyrifos: End-Use Products Cancellation Order. Available: http://www.epa.gov/fedrgstr/EPA-PEST/2002/January/Day25/p1764.htm 


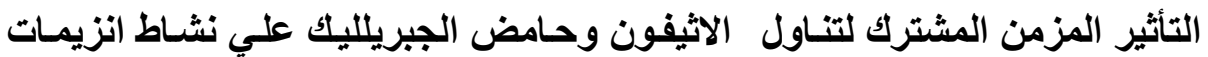

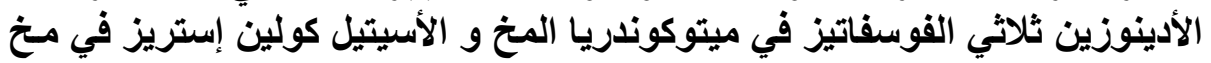
و دم الفئران

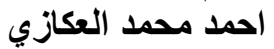

مركز البحوث الزراعية ـ المركز الأقليمي للأغذية و الأعلاف ـ الإسكندرية

يعتبر الأثثفون و حامض الجبريليك من منظمات النمو النباتية واسعة الإستعمال في محاصيل

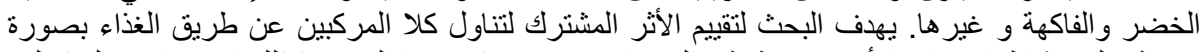

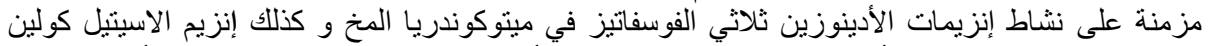

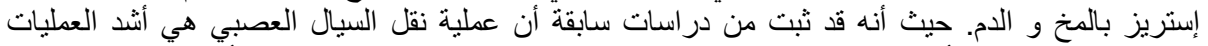

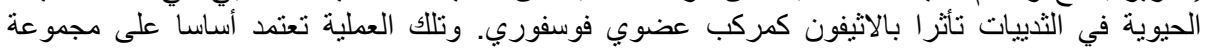

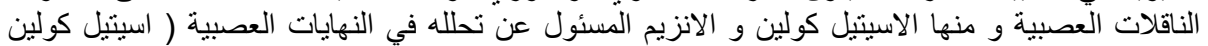

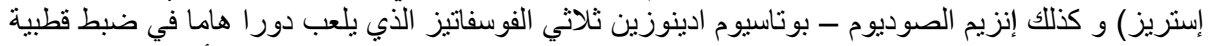

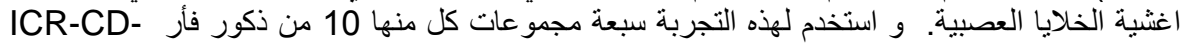

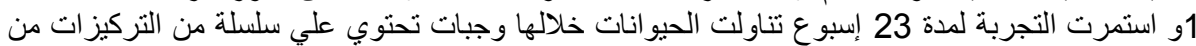

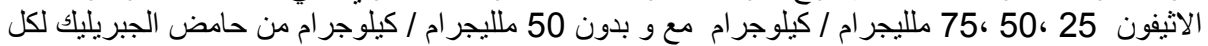

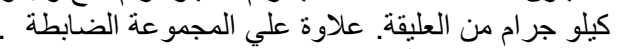

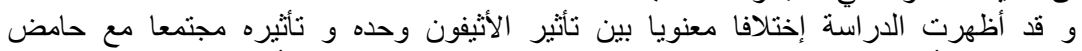

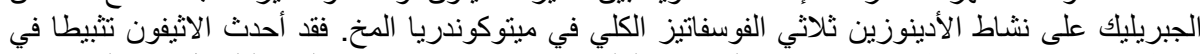

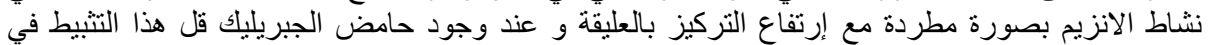

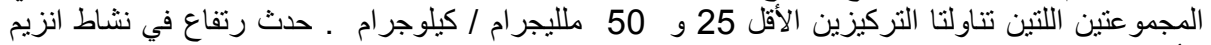

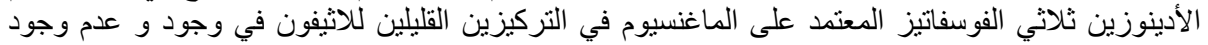

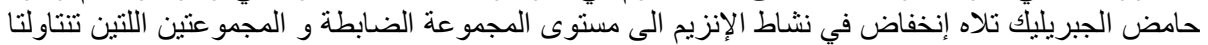

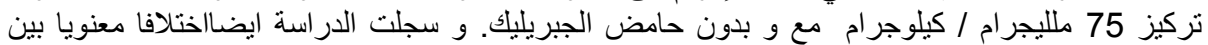

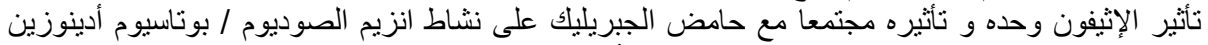

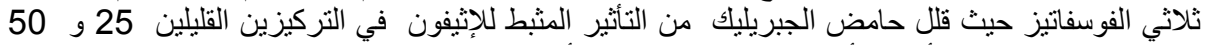

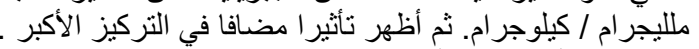

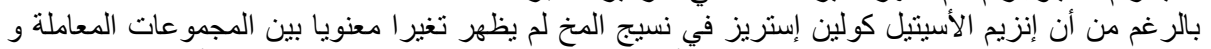

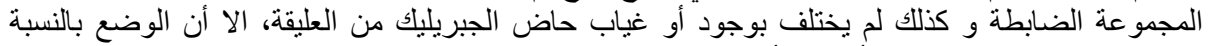

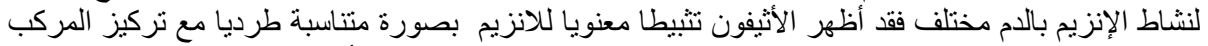

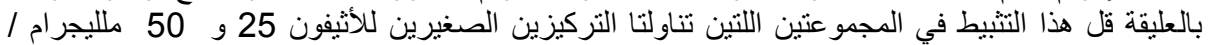

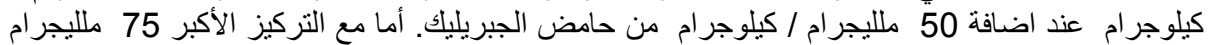

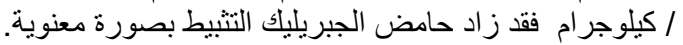

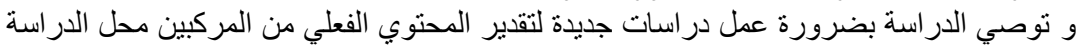

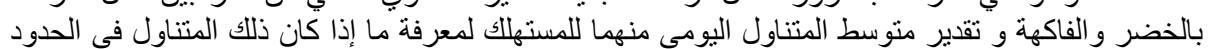

كلية الزراعة - جامعة المنصورة كلية الزراعة - جامعة الأزهر

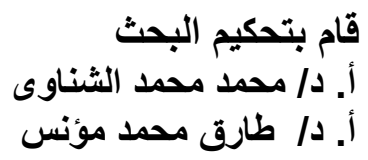

